\title{
Christian Theodor Vaupell, a Danish 19th century naturalist and a pioneering developer of the Quaternary geoscience
}

\author{
J. K. Nielsen ${ }^{1}$ and S. Helama ${ }^{2}$ \\ ${ }^{1}$ Statoil ASA, Development and Production Norway, Field Development, P.O. Box 273, 7501 Stjørdal, Norway \\ ${ }^{2}$ Finnish Forest Research Institute, Northern Regional Unit, P.O. Box 16, 96301 Rovaniemi, Finland \\ Correspondence to: J. K. Nielsen (taphofacies@ hotmail.com)
}

Received: 29 June 2012 - Revised: 6 August 2012 - Accepted: 20 August 2012 - Published: 5 September 2012

\begin{abstract}
Christian Theodor Vaupell (1821-1862) was a Danish scholar with pioneering investigations particularly on the late Quaternary development of bog forests, but also microscopy of plant anatomy and vegetative reproduction. His studies contributed to the early scientific thinking of the Quaternary environmental changes. Before his academic efforts, he had already survived the war between Prussia and Denmark albeit he became severely wounded and his left arm was amputated. The drama of his academic efforts, on the other hand, lies in the more or less suspicious dispute of his first doctoral thesis and his dismissal from the academic world during the following years. At the same time, he earned praise for his first thesis (never accepted as thesis but published as a regular book) from abroad; he was also able to attract private foundations for financial support of his scientific work. Following the enthusiasm of his time, Vaupell became attracted to the pine megafossils known to have been preserved in the bogs in north-west Europe. The megafossils led him to study not only the life systems of the ancient and modern bog forests but also their associations with Earth processes. As an interesting detail of his research, Vaupell made compound interpretations on the occurrence of megafossil stumps and their tree-ring growth patterns. In the course of the 20th century, Vaupell's studies have been cited as a general reference of post-glacial vegetation change and plant succession rather than clearly pioneering investigations of palaeoecology, an angle that we would like put into a contrasting perspective. To do so, we provide a brief portrait of Christian Vaupell and his research career. In conclusion, we wish to emphasize the comprehensiveness of Vaupell's views on the late Quaternary vegetation changes and the role of plant succession in that development.
\end{abstract}

\section{School days, early studies and military service}

Christian Vaupell was born in Kolding, Denmark, 14 October 1821, the son of Lieutenant colonel Johan Wilhelm Ludvig Vaupell and wife Margrethe Dorthea Karberg. Christian Vaupell attended the local school of which he remembered with gratitude. Seeds of inspiration were sown by those school teachers that were enthusiastic and keen to educate the pupils. Bryndum taught in history and geography, and Borgen guided the pupils out to botanize. During vacations, Christian Vaupell contributed with specimens to L. Hansen's herbarium in the duchies of Holstein and Schleswig.
By completing examen atrium in 1841, Vaupell qualified for admission to the university, where he became deeply interested in the societies of the antiquity and their relationship to the modern society, as well as theology. Vaupell took the examen philosophicum, and later received the academic degree candidatus theologia, from the University of Copenhagen in 1847. Shortly after, he continued with botany and obtained insights into the other natural sciences. He attended the lectures by Prof. Johan Georg Forchhammer about the geological periods and their flora and fauna. During botanical excursions, Vaupell (1845) noted how the Danish tree species occurrence depends on different soil conditions, notably in 


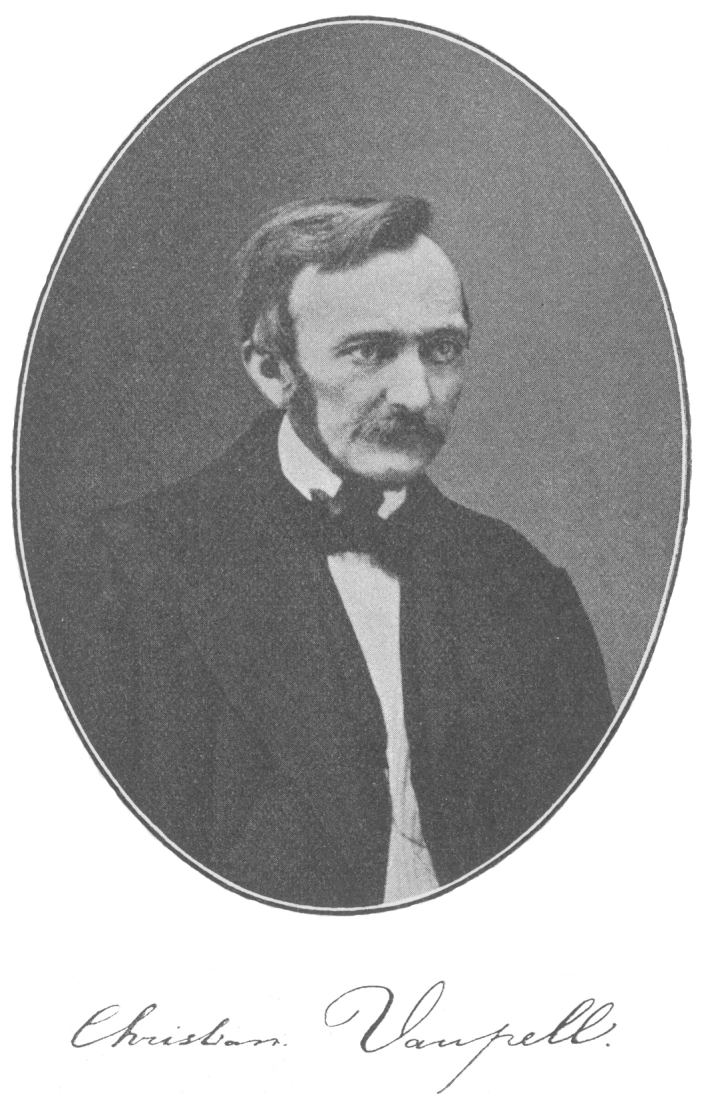

Figure 1. Christian Theodor Vaupell, portrait taken by Peder H. C. Most. Reproduced with kind permission by the editorial office of Bulletin of the Geological Society of Denmark (1906, Vol. 2, No. 12, p. 42). Original photograph at the Royal Library of Denmark.

Jutland. Besides studying chemistry, Vaupell also held botanical course for students at Det Landoekonomiske Institut (Institute of Farming Economy).

In 1848 Vaupell volunteered for the army and joined the 1st battalion, 2nd company. During the war between Prussia and Denmark, he became severely wounded on 23 April in Schleswig (O. Vaupell, 1863, p. 414). Because of gangrene his left arm was amputated, and the doctors had little hope for his survival. A projectile was cut out from the left side of the back spine. When he returned home, his health was weakening by tuberculosis. Subsequently, his health improved sufficiently so that Vaupell could become a scientific popularisator.

Vaupell continued at the von Westens Institute (Copenhagen), where he was a teacher in natural history 1845-1855 (Fig. 1). He also taught at Frøken Zahle's Institute (Copenhagen) (Wittrock, 1903, p. 105). His talent for popular science was shown by the launch of Tidsskrift for populare Fremstillinger af Naturvidenskaben (Journal for Popular Presentations of Natural Science) in 1854, together with friends zoologist Christian Frederik Lütken and geologist Carl Fogh. Vaupell's book, "Planterigets Naturhistorie, til Skolebrug"
("Natural history of the Vegetable Kingdom, for School Purposes", 1854a), was a major renewal of the educational literature and became reissued in the following three decades.

\section{Attraction of pine megafossils}

Christian Vaupell's interests in the geological periods and their flora and fauna during his studies could be seen to prefigure his later research interests in post-glacial vegetation history. In this respect, Vaupell was a child of his time. The subfossil stumps and trunks of pines - also called megafossils due to their relatively large size in relation to other fossil plant fragments - had begun to attract the naturalists of the time. These fossil specimens were particularly unusual for scholars assuming more or less stable environmental conditions through the time (Birks, 2008). Once the trunks started to gain public attention in Denmark, the Royal Danish Academy of Sciences and Letters offered a prize for "solving the problem" about how pine trees once grew on Danish bogs. The winner of the competition was supposed to illustrate what had caused the extinction of pine as a native tree in Denmark (Iversen, 1973; Birks, 2008; Birks and Seppä, 2010). As we see it today, the attraction of megafossils in general, and the competition in particular, paved a way for critical development of the Quaternary geoscience as well as for scientific thinking of the pre-historical environmental perturbations.

The particular prize was won by Johannes Japetus Smith Steenstrup (1813-1897) who proposed a climatic theory. In 1842 , he concluded that plant remains from peat bog deposits can be used to interpret changes in climate and correlation of vegetation with four distinct successive periods of forest vegetations. Such long-term changes were called successions. Steenstrup (1842) used the word succession for changes of broader significance than formerly done (Cowles, 1911). In fact, the term succession was originally used by Dureau de la Malle (1825) for the ecological development of clear-cut forests. Of note, Steenstrup was a lecturer on zoology at the Soroe Academy (1841-1846), becoming later a professor of zoology at the University of Copenhagen (Spärck, 1932). As stated by Birks (2008), Steenstrup could be regarded as one of the fathers of Holocene palaeoecology and climate research because of his findings.

It was some years later that Christian Vaupell started to conduct actual scientific research on these very same topics and proceeded for the path of having his career as an actively writing scientist. Between the years 1849 and 1851, Vaupell became oriented towards the similar research direction as Steenstrup as he gained experience in the field of postglacial botany. He began to analyse the species composition of leaves, wood and seeds based on the remains found in peat deposits of numerous bogs, in order to better understand the post-glacial development of temperate forests in his native land, Denmark. As we see it today, the understanding of his 
analyses was among the early pioneering studies of plant successions.

\section{Vaupell's theory of post-glacial vegetation changes}

Vaupell (1851) summarized the main conclusions on tree distribution in bog deposits: (1) the beech (Fagus) is absent; (2) the birch (Betula alba var. glutinosa Wahlroth) is the most common tree, present both below and above the pine accumulation, and in the same relation it stands to oak; (3) the Scots pine (Pinus sylvestris L. and the bog pine Pinus sylvestris femsöensis Vaupell) grows in the deepest layers, as well as near the surface; and (4) the oak (Quercus robur pedunculata Ehrhart) grows not in a certain location, but typically the oak layer is above the pine layer. Remains of aspen (Populus tremula L.), black alder (Alnus glutinosa L.), grey willow (Salix cinerea L.), eared willow (S. aurita L.) and hazel (Corylus avellana L.) may also be present in bog deposits. Innovatively, Vaupell (1851) considered the preservation potential of tree remains and their spatial distribution in bog deposits and rationalized that the absence of the beech could not be related to the preservation conditions in Danish bogs. Based on the layering of tree remains in forest bogs, Vaupell (1851) contrasted the evidence for Steenstrup's (1842) four successive periods of forest vegetations, those named for each certain species: (1) aspen and birch, (2) pine (3) oak, (4) alder. Instead, Vaupell (1851) concluded that the past forests were a mixture of conifers and deciduous trees. The birch was the most common tree, secondly pine and oak. Oak was a tolerant tree, distributing by gradual replacement of pine, like the beech does in the Danish plantations. On the bogs, the alder, birch and bog pine grew. Such was the forest composition in North Zealand and in many areas of northern and western Jutland. Other areas, particularly the east coast of southern Jutland and Schleswig, were characterized by solely deciduous forests where birch and oak were prevalent; pine did not grow in the forests, only on the bogs. These results were published in the book "De nordsjællandske Skovmoser. En botanisk-mikroskopisk Undersøgelse af de Plantedele, som danne Tørven, og af de Levninger af Fortidens Skove, der ere bevarede i nogle nordsjællandske Skovmoser" ("Forest Bogs in Northern Zealand. A botanical-microscopic investigation of the plant parts that make up the peat and of the remains of past forests that are preserved in some forest bogs in northern Zealand") (Vaupell, 1851).

Vaupell (1851) did not neglect the possible effect of climate proposed by Steenstrup (1842), but hard evidence was at that time unknown from bogs. It was not until 1871 that Alfred Gabriel Nathorst and Steenstrup found leaves indicative of Arctic and cool temperate climate (Betula nana, Dryas octopetala, Salix reticulata) in clay strata of a Danish bog (below the peat), i.e. evidence of early cold climate (Nathorst,
1914; Clément, 1921; Christensen, 1924-1926). But that evidence had not yet seen the daylight in the 1850s. Instead, Vaupell $(1851,1857,1858$ a) emphasized, as a new and farreaching theory, that forest development could be dependent upon the gradual alteration of soil nutrients, as well as sunlight and moisture conditions. In fact, he had already previously (Vaupell, 1845, 1854c) considered aspects of these parameters. He was also of opinion that the forest vegetation may change without any climate change. Birch, which can live under harder conditions than pine, may be found on sandy or acidic soil. For instance, soil becomes acidic in large perimeter of wet areas without drainage. Pine trees can live in more moisture and poorer soil than oak and beech. At improvement of the soil, birch and pine cannot stand the competition against other tree types. When the soil is even more developed, the beech takes over (Vaupell, 1851, 1857). Vaupell (1851) found it incomprehensible that there is no longer any natural occurrence of pine trees in Denmark. The subfossil bog pine is common near the peat surface, sometimes not even covered by peat. It is not many centuries ago that the bog pine grew on the bogs. Axe marks are present on the stems, some with evidence of fires; human beings may have contributed to the disappearance of pine. Vaupell (1851) wrote further that recent pines derived from plantations in North Zealand may live on bogs.

At a researcher meeting in Kiel, Prof. J. G. Forchhammer (cited by Vaupell, 1851) stated that the disappearance of pine was caused by milder climate and explained Steenstrup's forest succession with a past seaway between the White Sea and the Gulf of Bothnia. He claimed that a cold sea current came towards Denmark through the Baltic Sea or a past seaway across the mid Sweden. Isostatic uplift of the Scandinavian Peninsula affected the seaway. At the meeting, Forchhammer also stated the present northern limits of tree species as evidence for Steenstrup's forest succession. However, Vaupell (1851) did not find the sea current theory necessary and emphasized that the tree species do not have individual geographical growth zones. The Danish flora is mostly equal to the German flora, which lives under quite similar biogeographical conditions; almost no Nordic plants have their southern limit in Denmark. According to Vaupell (1851), birch, which is not preferentially a Nordic tree, is also common in Germany, even on plains. The climate could therefore not have caused its replacement. Vaupell (1851) also emphasized that the disappearance of the natural Scots pine from the Danish forests cannot be an evidence for milder climate. The Scots pine exists in countries with milder or colder climate where the climate is more humid or drier than in Denmark (Vaupell, 1851). Furthermore, Vaupell (1851) argued for non-climatically related changes by referring to studies showing that the deciduous forests in North Germany are gradually being replaced by Scots pine and spruce. The Harz forests had been fully replaced by Scots pine during the last centuries. 


\section{Studying tree-ring patterns in megafossil trunks}

A significant feature of Vaupell's (1851) work was its dedication to study the growth patterns of tree-rings as observed from the cross-section surfaces of the megafossils. He also made notes on the colour of the wood as well as the size of the wood cells, but, primarily, Vaupell appears to have understood that the tree-rings could be used to make interpretations on the climatic and environmental conditions that had prevailed during the ancient lives of the bog pines. Notably, Vaupell (1851) put his observations on fossil tree-rings into the context of the findings in modern forest research. Particularly, he referenced the article by Bravais and Martins (1843). This was a thorough work on the growth of standing pines, studying the recent growth variations of same species as Vaupell (1851) across northern Europe.

Combining his own findings with those of Bravais and Martins (1843), Vaupell (1851) noticed that the widths of the tree-rings and the shape of their growth curves not only depended on climate but also the density of the stand as well as the soil conditions. Yet, he regarded the climate as the primary factor behind these growth variations. In terms of biogeography, Vaupell (1951) related the bog pine growth of his own investigations more to the Central European pine growth, rather than northern type of growth patterns, due to the appearances between the growth patterns. It is noteworthy that, akin to his analyses on past vegetations changes, Vaupell (1851) did not hesitate to use the present as a key to interpret the past growing conditions based on his observations on fossil tree-rings, the principle that follows the concepts of methodological uniformitarianism (sensu Gould, 1965).

\section{Aftermath of Vaupell's 1851 book}

Following the publications of this work on post-glacial vegetation history, Vaupell applied to the Royal Academy of Science and Letters for funding of further studies of fossil trees in 1852. Inside the Academy, Prof. J. J. S. Steenstrup particularly argued for an evaluation committee, which then came to comprise Prof. J. G. Forchhammer, Prof. F. M. Liebmann and himself (Lomholt, 1950). The committee was regarded by Prof. Henrik Nikolai Krøyer and Jørgen Matthias Christian Schiødte as an attempt to discredit Vaupell for being unsuitable for science. They recognized the ethical issue and unsuccessfully - recommended a common voting about the funding application (Lomholt, 1950). Despite the rejection, Vaupell submitted a manuscript about Tertiary tree remains to the Academy in 1853. The manuscript was to be evaluated by Steenstrup as well as Liebmann and Forchhammer (Syrach Larsen, 1923; Lomholt, 1950). The following year Vaupell withdrew the manuscript, which became published posthumously, as late as in 1906. It is known that rivalries between Steenstrup and colleagues about positions and professional duties occurred (e.g. Collin, 1901; Syrach Larsen,
1923; Christensen, 1924-1926; Lomholt, 1950). In addition, Steenstrup represented a natural philosophical, rather speculative school, whereas Schiødte's circle stood for exact descriptive natural science (sensu Spärck, 1932).

Continuing with scientific career, Vaupell proceeded to write his doctoral thesis or, as a matter of fact, theses. As we know today, this attempt turned out to became a rough passage until the final acceptance. The first thesis manuscript was about rootstocks (rhizome). The work became of "unclear reasons" rejected for doctoral defence (Vaupell, 1863). Although formal and stylistic errors were corrected, Prof. Liebmann told Vaupell that the thesis would never be accepted. It would thus appear rather clear that the reasons of rejection were not scientific. Later, Syrach Larsen (1923), Christensen (1924-1926) and Lomholt (1950) clarified that Prof. Steenstrup felt insulted by Vaupell's different results from forest bogs. Vaupell (1851) correctly assigned tree remains to other subgeneric taxa (Christensen, 1924-1926). On scientifically solid grounds, Vaupell $(1851,1857,1858$ a) had emphasized the importance of soil development and sunlight for postglacial forest development, which was an alternative theory to Steenstrup's (1842) theory about climate control. Nevertheless, the thesis manuscript of Vaupell was printed in both Danish and German (Vaupell, 1854b, 1855a), and its conclusions became widely accepted in Germany and France, for instance. Later, Vaupell (1859a, c) wrote a second thesis manuscript that was about fertilization in the genus Oedogonium (freshwater algae). This work became accepted for defence of the doctoral degree at the University of Copenhagen. Vaupell had finally earned his doctorate, only three years before his death.

\section{A taste of international recognition}

Vaupell did also extensive travelling. He travelled through Jutland twice to examine recent flora and plant fossils in lignite (Vaupell, 1906; see also Garboe, 1946). Further travelling was funded by Kommunitetet, Det Kongelige Danske Landhusholdningsselskab and Det Rejersenske Fond. Visits were made in 1855-1856 to the neighbouring countries, Hannover and Holland, to visit the field environments with soil conditions comparative to Denmark. Vaupell continued to France, where he thrived in the international environment of Paris and Nice. He was gladly received by colleagues (e.g. the botanists Claudio Gay Mouret and Pierre Louis François Lévêque de Vilmorin) at Jardin des Plantes (Muséum national d'Histoire naturelle) and the botanical library of Jules Paul Benjamin Delessert.

During his excursions in Provence, leafing was studied and material for physiological investigations was collected (Vaupell, 1858d). Studies of olive trees and wine plant farming and growth conditions became later published by Vaupell $(1858 \mathrm{~b}, \mathrm{c})$, as well as observations on Nice's winter flora (1859b). The Société botanique de France had chosen 
him as vice-president, and an excursion was arranged to Auvergne (Puy-de-Dôme) and the mountains of volcanoes around Clermont-Ferrand. In a forest of beech and firs, Vaupell presented the theory about the beech and its immigration into Danish forests. Immediately, Prof. Joseph Decaisne (Jardin des Plantes) encouraged him to publish the theory. As a result from the excursions and the extended field work, the book, "Bøgens Indvandring i de Danske Skove" ("Immigration of the Beech into the Danish Forests") was published in 1857 (see also Vaupell, 1858a) and the monograph received international attention. Overall, Vaupell was the first botanist of the modern school in Denmark, with expertise in plant biology, ecology and anatomy (Christensen, 1924-1926).

\section{Continuing career}

Vaupell received support from Det Smithske Legat (The scholarship of Smith), which was founded 1848 by assessor J. L. Smith (1789-1849). At that time, the scholarship was the largest at the university and only provided to those with particular talent. Contemporaneously, he conducted microscopy of algae to unravel their biology and reproduction by spores, and developmental history (Vaupell, 1855b, c).

Vaupell (1863) mentioned exchange of plant material with Prof. Frederik Michael Liebmann (University of Copenhagen). After the death of Prof. Liebmann in 1856, Vaupell felt ignored by Danish university colleagues. Vaupell's autobiography may reflect some bitterness (see Hartz in Vaupell, 1906). He was not offered a permanent post, probably not because of personal reasons but limited available positions (Christensen, 1924-1926). Instead, Det Kongelige Danske Landhusholdningsselskab showed great courtesy and encouraged him in 1858 to give lectures about farming of culture plants. Det Kongelige Danske Landhusholdningsselskab also financially supported Vaupell's domestic travels between the years 1859 and 1861. Agriculture and forestry gave him full recognition (Christensen, 1924-1926). During the period 1860-1862, Vaupell was a private docent (lecturer) at the university and gave lectures about the Danish forests, inspiring the young Johannes Eugenius Bülow Warming among others. For a living, however, he continued with hours teaching at Frøken Zahle's Institute (Warming, 1881).

At age of only 40, Vaupell died of lung disease in Copenhagen, 15 September 1862. Until a few days before his death, Vaupell was still working with great zeal to finish his very last book, "De danske Skove" ("The Danish Forests", 1863). Most of the book was in the proofing process. A friend, G. Ploug, promised to make certain that the book became published. A draft for an autobiography, which was found among the possessions of Vaupell, was added to the book (Vaupell, 1863, p. III-XII). In addition to the autobiography, information has also been compiled by Warming (1881, p. 185-188), Wittrock (1903, p. 105), Syrach Larsen (1923) and Christensen (1924-1926, vol. 1, p. 472-498, vol. 2, p. 288-292).

Vaupell is buried in the Garnison's cemetery.

\section{Legacy}

Christian Theodor Vaupell is still remembered - albeit by a relatively limited number of scholars - for his scientific articles published as monographs not only concerning the post-glacial forest development, but also microscopy of plant anatomy and vegetative reproduction. This article has focused on Vaupell's studies and scientific thinking particularly on late Quaternary phenomena and, in particular, palaeoecology and vegetation changes since the ice age. In this respect, the career of Vaupell could be viewed in the context of the emergent development of the Quaternary studies as conducted during the 19th century. Briefly, Vaupell provided the late Quaternary megafossils with a context of contemporaneous ecology, with elaborated understanding of plant successions as adapted from his experience in forest science.

Moreover, Vaupell's career could be characterized by his misadventures in the university life. The more or less suspicious rejection of his first doctoral thesis manuscript must have affected him mentally; later, Vaupell was not offered a permanent post (Christensen, 1924-1926), but he continued with hours teaching at Frøken Zahle's Institute (Warming, 1881). It may not be an oversimplification to state that Vaupell's career achievements were overshadowed by the contemporaneous activities of J. J. S. Steenstrup. As previously alluded to, Steenstrup was a lecturer (Soroe Academy) and later professor of zoology at the University of Copenhagen. Steenstrup had a prolific scientific authorship and attained a role as one of the leading characters of the University until his death (Spärck, 1932).

The theory of plant succession began to emerge vigorously during the late 19th and early 20th century. Among the developers of the theory, both Henry Chandler Cowles (1869-1939) (see Adams and Fuller, 1940) and Frederic Edward Clements (1874-1945) (see Egerton, 2009) recognized the works of Vaupell $(1851,1857,1863)$. Cowles (1911) expressed his gratitude to Vaupell as he noted that the latter "gave to the world his famous account of the postglacial development of Danish vegetation, showing that birch was the chief early pioneer, and that later it was followed in turn by pine and oak, and finally by the beech, which dominates to-day.", by referring to the works of Vaupell $(1851,1857)$. In the parts of his books where the early investigations of plant succession were reviewed, Clements $(1916,1928)$ explained Vaupell (1857) as having discussed the "invasion of beech into Denmark" and reviewed the "evidence obtained from submerged forests, deposits of calcareous tufa and peatbogs". Clements $(1916,1928)$ further explained that Vaupell (1857) concluded that the "beech had migrated from its centre in France and Germany during the present geological 
period, establishing itself wherever the soil became drier or richer, and dispossessing birches and pines everywhere but in marshy or sterile soil". Clearly, the two American ecologists were conscious of Vaupell's investigations, Cowles (1911) shortly focusing on his explorations on post-glacial vegetation history, Clements $(1916,1928)$ emphasizing Vaupell's ideas on the importance of soil in determining the plant succession.

Later general reviews, even those providing historical insights of plant succession research (e.g. Whittaker, 1953; McIntosh, 1981; Egerton, 2009), have not often remembered Vaupell's studies. Exceptions to these are the reviews on the development of Quaternary science that emphasize (Iversen, 1973) or at least mention (Birks, 2008; Birks and Seppä, 2010) the achievements of Vaupell within the trajectory of the discipline. Among his books and articles, the recently most recognized is his posthumously published monograph "De danske Skove" (Vaupell, 1863), at least as it has become cited eight times over the past $25 \mathrm{yr}$ (Google Scholar (http://scholar.google.com/), accessed 15 March 2012). Actually, the book has been reprinted (Vaupell, 1986) and one additional research paper (Lawesson and Oksanen, 2002) cited that edition of the book. Among these, the study of Vaupell (1863) is most commonly cited merely as general reference. Such occasions are the utterances as follows: "Forests have been a major object of study since the middle of the previous century" (Lawesson, 1998); "Alnus glutinosa was previously widespread in Danish forests" (Lawesson, 2000); or "The long-term replacement of mixed Quercus communities by Fagus, for example, has been observed in Denmark" (Bradshaw et al., 2005).

Other recent studies have used the descriptions of Vaupell (1863) as historical guidebooks to portray the 19th century forested landscapes in their study localities in Denmark. As an example, Tybirk and Strandberg (1999) provided a map of deciduous forests and shrubs around their study region (Hald Ege, Denmark) for year 1800, as reconstructed from the actual map of Vaupell (1863), who had described the existing forest at the time of his writing as well as descriptions of former coherent forests and shrubs according to Vaupell (1863). Moreover, Emborg et al. (2000) made reference to Vaupell (1863) to point out that the forests of their study region (Suserup Skov, Denmark) had been managed only by minimal intervention until the 1850 s.

The research ideas of Vaupell clearly pioneered the study of plant succession. According to his investigations from the late Quaternary peat deposits in Denmark, Vaupell (1851, 1857,1858 a) focused on the importance of soil development and sunlight for plant succession, as an alternative theory to Steenstrup's (1842) theory of climate as a driving agent. Albeit he did not ignore the climate as a potential factor of long-term changes in the plant communities, Vaupell (1851, 1857,1858 a) presented quite a breakaway from the prizewinning theory of Steenstrup (1842). Nevertheless, the articles of Vaupell were to a great majority published in Danish, a second fact that likely disrupted international awareness of Vaupell's scientific discoveries and his novel way of thinking about the plant succession, both in the contexts of Quaternary and forest sciences.

Moreover, the tree-ring studies of Vaupell (1851) preceded the recently growing interest on the tree-ring series as recovered from Holocene megafossils. Similarly to Vaupell, many of these studies concentrate on the growth of the bog pines in relation to past climate variability (Leuschner et al., 2007; Eckstein et al., 2009; Moir et al., 2010; Edvardsson et al., 2012). Some of the megafossil studies have likewise interpreted the growth patterns and the shapes of the tree-ring curves in the context of the environmental changes through time (Spurk et al., 2002; Helama et al., 2005; Schaub et al., 2008). It should be borne in mind, however, that, whereas the recent tree-ring studies aim to dendrochronologically date the megafossils to calendar-year scale, this was never in the realms of Vaupell's investigations. Actually, the systematic dating of wood by means of tree-rings did not come to light until the early part of the 20th century (Douglass, 1921, 1941).

An inherent aspect of Vaupell's research was his ability in interpreting the associations between the Earth and life processes through the post-glacial times. This is how his attitude towards reading the fossil record intimately resembles the way the fossils are explored in the context of the recently emerging geoscientific subdiscipline - geobiology (e.g. Olszewski, 2001; Noffke, 2002). This is a subfield of palaeontology with the theme to "provide new insights into the interactions and feedbacks among the biosphere, atmosphere, hydrosphere, and lithosphere with implications for modern environmental and ecological change as well as past events" (Olszewski, 2001). Focusing on these interactions, through the vegetation, soil, nutrient, moisture, sunlight and climate processes, Vaupell's thinking remarkably predates the ongoing ascent of geobiology. Indeed, the geobiological analyses have been considered as one of the future directions of palaeontological research (Olszewski, 2001).

\section{Concluding remarks}

Christian Theodor Vaupell was a Danish 19th century naturalist. He was altogether a well-educated man; before pursuing the explorations in natural science, he took the examen philosophicum as well as received the academic degree of candidatus theologia. In the field of natural science, his activities spanned the 1850s, during which most of his research was published. Vaupell's research interests dealt with several disciplines, albeit his major works could be characterized to have concerned the late Quaternary geoscience, the longterm vegetation changes through the post-glacial period, and the development of Danish forests. Overall, in the modern school in Denmark, Vaupell was the first botanist having significant expertise in plant biology, ecology and anatomy. By 
studying the late Quaternary peat deposits in Denmark, Vaupell explained the pre-historic vegetation changes using multiple parameters including sunlight, soil nutrient and moisture development, not necessarily climate. This is how his theory of vegetation changes pioneered the study of plant succession. The fact that Vaupell may well have been the first to use the tree-ring growth patterns as observed from the pine megafossils he analysed, to derive more elucidated interpretations of their life and death, further shows his innovative skills of exploiting the fossil materials. Focusing tightly on the processes of the Earth-life system associations through time, his thinking predates the ascent of the geoscientific subdiscipline of geobiology, which has recently been considered as one of the future directions of palaeontological research.

It appears that the scientific significance of Vaupell's work did not receive the recognition as could be expected by his achievements. The most obvious reason for this may be the language barrier as Vaupell mostly published his research articles in his native language, Danish, with only rare exceptions of German and French volumes. Other reasons might originate from the doubtful rejection of his first thesis manuscript, an episode that likely delayed his career and obstructed him to receive rightful academic acknowledgments for his scientific accomplishments within disciplines he represented. The shortness of Vaupell's active career did not bestow him to earn professor's chair, the academic position which, if materialized, would have likely widened his realms of research possibilities as well as visibility of his work. Vaupell died early at the age of only 40 not long after he had acquired a taste of recognition as a multi-disciplinary scholar from his French colleagues. Foreseeably, his career ended before achieving its summit.

Acknowledgements. The work of $\mathrm{SH}$ was supported by the Academy of Finland. The authors thank the referees for comments.

Edited by: G. P. Gregori

Reviewed by: K. Storedvedt

\section{References}

Adams, C. C. and Fuller, G. D.: Henry Chandler Cowles, physiographic plant ecologist, Ann. Assoc. Am. Geogr., 30, 39-43, 1940.

Birks, H. J. B.: Holocene climate research - progress, paradigms, and problems, in: Natural Climate Variability and Global Warming: a Holocene Perspective, edited by: Battarbee, R. W. and Binney, H., Wiley-Blackwell, Chichester, 7-57, 2008.

Birks, H. J. B. and Seppä, H.: Late-Quaternary palaeoclimatic research in Fennoscandia - a historical review, Boreas, 39, 655673, 2010.

Bradshaw, R. H. W., Wolf, A., and Møller, P. F.: Long-term succession in a Danish temperate deciduous forest, Ecography, 28, 157-164, 2005.

Bravais, A. and Martins, C.: Recherches sur la croissance du Pin sylvestre dans le nord de l'Europe, Mémoires Couronnés et
Mémoires des Savants Étrangers, publies par l'Académie Royale des Sciences et Belles-Lettres de Bruxelles, 15, 2e partie, 18411842, 1-64, 1 plate, 1843.

Christensen, C.: Den danske Botaniks Historie med tilhørende Bibliografi, H. Hagerups Forlag, København, 1, 884 pp., 2, 680 pp., 1924-1926 (in Danish).

Clément, A.: A. G. Nathorst. Mindeord den 31. januar 1921, Meddelelser fra Dansk geologisk Forening, 6, 1-8, 1921 (in Danish).

Clements, F. E.: Plant Succession. An Analysis of the Development of Vegetation, Carnegie Institution of Washington, Washington, 242, 512 pp., 1916.

Clements, F. E.: Plant Succession and Indicators. A Definitive Edition of Plant Succession and Plant Indicators, The H. W. Wilson Company, New York City, 453 pp., 1928.

Collin, J.: Schiødte, Jørgen Matthias Christian, in: Dansk Biografisk Lexikon, tillige omfattende Norge for Tidsrummet 1537-1814. XV. Bind Scalabrini - Skanke, edited by: Bricka, C. F., Gyldendalske Boghandels Forlag, Nordisk Forlag, Kjøbenhavn, 149154, 1901 (in Danish).

Cowles, H. C.: The causes of vegetational cycles, Ann. Assoc. Am. Geogr., 1, 3-20, 1911.

Douglass, A. E.: Dating our prehistoric ruins, Nat. Hist., 21, 27-30, 1921.

Douglass, A. E.: Crossdating in dendrochronology, J. Forest., 39, 825-831, 1941.

Dureau de la Malle, A. J. C. A.: Mémoire sur l'alternance ou sur ce problème: la succession alternative dans la reproduction des espèces végétales vivant en société, est-elle une loi générale de la nature?, Ann. Sci. Nat., 5, 353-381, 1825.

Eckstein, J., Leuschner, H. H., Bauerochse, A., and Sass-Klaassen, U.: Subfossil bog-pine horizons document climate and ecosystem changes during the Mid-Holocene, Dendrochronologia, 27, 129-146, 2009.

Edvardsson, J., Leuschner, H. H., Linderson, H., Linderholm, H. W., and Hammarlund, D.: South Swedish bog pines as indicators of Mid-Holocene climate variability, Dendrochronlogia, 30, 93103, 2012.

Egerton, F. N.: Homage to Frederic E. Clements, historian of plant succession studies, Bulletin of the Ecological Society of America, 90, 43-79, 2009.

Emborg, J., Christensen, M., and Heilmann-Clausen, J.: The structural dynamics of Suserup Skov, a near-natural temperate deciduous forest in Denmark, Forest Ecol. Manag., 126, 173-189, 2000.

Garboe, A.: Thomas Bartholin og Rav-Studiet i Danmark, Meddelelser fra Dansk geologisk Forening, 11, 97-116, 1946 (in Danish).

Gould, S. J.: Is uniformitarianism necessary, Am. J. Sci., 263, $223-$ 228, 1965.

Helama, S., Lindholm, M., Timonen, M., and Eronen, M.: Mid and late Holocene tree population density changes in northern Fennoscandia derived by a new method using megafossil pines and their treering series, J. Quaternary Sci., 20, 567-575, 2005.

Iversen, J.: The development of Denmark's nature since the last glacial, Danmarks Geologiske Undersøgelse, 5. Series, 7-C, 1126, 1973.

Lawesson, J. E.: Quantitative vegetation ecology in Denmark, J. Veg. Sci., 9, 891-896, 1998.

Lawesson, J. E.: Danish deciduous forest types, Plant Ecol., 151, 199-221, 2000. 
Lawesson, J. E. and Oksanen, J.: Niche characteristics of Danish woody species as derived from coenoclines, J. Veg. Sci., 13, 279$290,2002$.

Leuschner, H. H., Bauerochse, A., and Metzler, A.: Environmental change, bog history and human impact around 2900 B.C. in NW Germany - preliminary results from a dendroecological study of a sub-fossil pine woodland at Campemoor, Dümmer Basin, Veg. Hist. Archaeobot., 16, 183-195, 2007.

Lomholt, A.: Det Kongelige Danske Videnskabernes Selskab 1742-1942, Samlinger til Selskabets Historie, E. Munksgaard, København, 2, 599 pp., 1950 (in Danish).

McIntosh, R. P.: Succession and Ecological Theory, in: Forest Succession. Concepts and Application, edited by: West, D. C., Shugart, H. H., and Botkin, D. B., Springer-Verlag, New York, 10-23, 1981.

Moir, A. K., Leroy, S. A. G., Brown, D., and Collins, P. E. F.: Dendrochronological evidence for a lower water-table on peatland around 3200-3000 BC from subfossil pine in northern Scotland, The Holocene, 20, 931-942, 2010.

Nathorst, A. G.: Minnen från samarbete med Japetus Steenstrup 1871 och från en därpå följande tjugofemårig korrespondens, in: Mindeskrift i Anledning af Hundredaaret for Japetus Steenstrups Fødsel, edited by: Jungersen, H. F. E. and Warming, E., Bianco Lunos Bogtrykkeri, København, chapter 5, 1-22, 1914 (in Swedish).

Noffke, N.: The concept of geobiological studies: the example of bacterially generated structures in physical sedimentary systems, Palaios, 17, 531-532, 2002.

Olswewski, T. D.: Geobiology: a golden opportunity and a call to action, Palaios, 16, 533-534, 2001.

Schaub, M., Büntgen, U., Kaiser, K. F., Kromer, B., Talamo, S., Andersen, K. K., and Rasmussen, S. O.: Late glacial environmental variability from Swiss tree rings, Quaternary Sci. Rev., 27, 2941, 2008.

Spärck, R.: Japetus Steenstrup, in: Prominent Danish Scientists through the Ages with Facsimiles from Their Works, edited by: Meisen, V., Levin \& Munksgaard, Copenhagen, 115-119, 1932.

Spurk, M., Leuschner, H. H., Baillie, M. G. L., Briffa, K. R., and Friedrich, M.: Depositional frequency of German subfossil oaks: climatically and nonclimatically induced fluctuations in the Holocene, The Holocene, 12, 707-715, 2002.

Steenstrup, J. J. S.: Geognostisk-geologisk Undersøgelse af Skovmoserne Vidnesdam og Lillemose i det nordlige Sjælland, ledsaget af sammenlignende Bemærkninger hentede fra Danmarks Skov-, Kjær og Lyngmoser i Almindelighed, Det Kongelige Danske Videnskabernes Selskabs Naturvidenskabelige og Mathematiske Afhandlinger, 9, 17-120, 1842 (in Danish).

Syrach Larsen, C.: Christian Theodor Vaupell, Naturens Verden, 7, 164-176, 1923 (in Danish).

Tybirk, K. and Strandberg, B.: Oak forest development as a result of historical land-use patterns and present nitrogen deposition, Forest Ecol. Manag., 114, 97-106, 1999.

Vaupell, C.: Bemærkninger over nogle danske Træarters Forekomst, Dansk Ugeskrift, 2. Series, 8, 72-80, 1845 (in Danish).

Vaupell, C.: De nordsjællandske Skovmoser. En botaniskmikroskopisk Undersøgelse af de Plantedele, som danne Tørven, og af de Levninger af Fortidens Skove, der ere bevarede i nogle nordsjællandske Skovmoser, C.A. Reitzel, Kjøbenhavn, 58 pp., 2 plates, 1851 (in Danish).
Vaupell, C.: Planterigets Naturhistorie, til Skolebrug, Reitzels Forlag, Kjøbenhavn, 197 pp., 1854a (in Danish).

Vaupell, C.: Om Karbundternes peripheriske Vægt i de dicotyledone Planters Mellemstokke, Videnskabelige Meddelelser fra Dansk Naturhistorisk Forening, Kjøbenhavn, 1854, 49-94, 2 plates, $1854 \mathrm{~b}$ (in Danish).

Vaupell, C.: Om Træernes Forgrening, Tidsskrift for populære Fremstillinger af Naturvidenskaben, 1, 53-71, 1854c (in Danish).

Vaupell, C.: Untersuchungen über das peripherische Wachsthum der Gefässbündel der dicotyledonen Rhizome, Leipzig, 44 pp., 2 plates, $1855 \mathrm{a}$.

Vaupell, C.: Om Sværmsporerne og Befrugtningen hos Algerne I, Tidsskrift for populære Fremstillinger af Naturvidenskaben, 2, 161-183, 1855b (in Danish).

Vaupell, C.: Om Sværmsporerne og Befrugtningen hos Algerne II. Befrugtningen hos Tangarterne, Tidsskrift for populære Fremstillinger af Naturvidenskaben, 2, 239-249, 1855c (in Danish).

Vaupell, C.: Bøgens Indvandring i de Danske Skove, C. A. Reitzels Bo og Arvinger, Kjøbenhavn, 63 pp., 1857 (in Danish).

Vaupell, C.: De l'invasion du hêtre dans les forèts du Danemark, Ann. Sci. Nat. Bot., 4. Series, 7, 55-86, 1858a.

Vaupell, C.: Oliventræet i Provence, Tidsskrift for populære Fremstillinger af Naturvidenskaben, 5, 181-200, 1858b (in Danish).

Vaupell, C.: Viinstokkens Dyrkning i Frankrig, Tidsskrift for populære Fremstillinger af Naturvidenskaben, 5, 262-283, 1858c (in Danish).

Vaupell, C.: Mentone og Monaco. En Reiseerindring fra Vinteren 1856, Dansk Maanedsskrift, 8, 449-482, 1858d (in Danish).

Vaupell, C.: Iagttagelser over Befrugtningen hos en Art af Slægten Oedogonium, Dr. Phil. thesis, C. A. Reitzel, Kjøbenhavn, 38 pp., 1859a (in Danish).

Vaupell C.: Nizzas Vinterflora, Videnskabelige Meddelelser fra Dansk Naturhistorisk Forening, 1858, 129-171, 1859b (in Danish).

Vaupell, C.: Sur le reproduction et la fécundation d'une espére du genre Oedogonium, Ann. Sci. Nat. Bot., 4. Series, 11, 192-204, 2 plates, 1859c.

Vaupell, C.: De danske Skove, P. G. Philipsens Forlag, Kjøbenhavn, foreword by G. Ploug, 309 pp., 1863 (in Danish).

Vaupell, C.: En botanisk Undersøgelse af det fossile Træ, der findes i Leer- og Sandlagene i Danmark og af Havet opkastes med Ravet paa de danske Kyster, Forword by N. Hartz, Meddelelser fra Dansk Geologisk Forening, 2, 43-64, 1906 (in Danish).

Vaupell, C.: De danske Skove, 2nd Edn., Dansk Skovforening, Forlaget Skippershoved, Ebeltoft, 309 pp., 2 plates, 1986 (in Danish).

Vaupell, O.: Kampen for Sønderjylland 1848-50, Den Danske Historiske Forening, Kjøbenhavn, 1, 416 pp., 1863 (in Danish).

Warming, E.: Den Danske Botaniske Literatur. Fra De Ældste Tider Til 1880. Offprint of Botanisk Tidsskrift 12, 1880, Carl Lunds Bogtrykkeri, Kjøbenhavn, 42-247, 1881 (in Danish).

Whittaker, R. H.: A consideration of climax theory: the climax as a population and pattern, Ecol. Monogr., 23, 41-78, 1953.

Wittrock, V. B.: Illustrerad förteckning öfver Bergielunds botaniska trädgårds samling porträtt af botaniska författare; jämte biografiska notiser, Meddelanden frän Kongliga Svenska Vetenskaps-Akademiens Trädgård Bergielund, Bergianska Stiftelsen, Stockholm, 3, 1-198, 37 plates, 1903 (in Swedish). 